\title{
Phytotoxicity Response of Pear to Application of Abamectin-Oil Combinations
}

\author{
R.J. Hilton, H. Riedl', and P.H. Westigard \\ Oregon State University, Southern Oregon Experiment Station, 569 \\ Hanley Road, Medford, OR 97502
}

Additional index words. Pyrus communis, Tetranychus urticae, spider mite, miticide

\begin{abstract}
Handgun treatments of abamectin and oil applied between mid-June and late August caused distinct epidermal rings where drops of spray liquid dried on the surface of pear fruit (Pyrus communis $\mathbf{L}$.). The severity of epidermal injury was related to the concentration of oil in the abamectin spray mixture (abamectin applied without oil caused no fruit damage). Of six pear cultivars tested, 'Anjou' was most susceptible to injury, followed by 'Cornice' and 'Bartlett'. 'Sensation Red Bartlett', 'Bosc', and 'Seckel' showed little or no phytotoxicity symptoms from abamectin and oil treatments with oil concentrations from $0.125 \%$ to $2.0 \%(v / v)$. On sensitive cultivars, the concentration of oil should not exceed $0.25 \%(\mathrm{v} / \mathrm{v})$ when combined with abamectin to reduce the risk of epidermal injury. Oil at $0.25 \%$ provides for adequate leaf penetration of abamectin and results in commercially acceptable spider mite (Tetranychus urticae Koch) control. Chemical names used: avermectin $B_{1}$ (abamectin).
\end{abstract}

Horticultural spray oils are widely used by themselves or in combination with other pesticides before bloom on pear for control of major pest species. Oil use during the summer, however, has not been very common in the pear-growing areas of the Pacific Northwest because of possible phytotoxicity to foliage and fruit (Willett and Westigard,

Received for publication 25 Nov. 1991. Accepted for publication 8 July 1992. The cost of publishing this paper was defrayed in part by the payment of page charges. Under postal regulations, this paper therefore must be hereby marked advertisement solely to indicate this fact.

${ }^{1}$ Mid-Columbia Agricultural Research and Extension Center, Oregon State Univ., Hood River, OR 97031.
1988). Despite this concern, foliar use of horticultural spray oils has increased in recent years in selective or "soft" chemical control programs that attempt to maximize the effects of natural control agents such as predators and parasitoids (Westigard et al., 1986).

The introduction of abamectin for suppression of several pear pests, including spider mites and pear psylla, has further increased oil use during the foliar period. This new miticide/insecticide, a macrocyclic lactone produced by the actinomycete Streptomyces avermitilis, is more effective on pear when applied in combination with oil. Apparently, oil aids in leaf penetration and improves its activity against some pest species (Anderson et al., 1986). Abamectin does not appear to be unduly harmful to predatory species such as the western predatory mite, Typhlodromus occidentalis Nesbitt, and thus may become an important component in an integrated pest management program on pears (Grafton-Cardwell and Hoy, 1983; Hoy and Cave, 1985).

In 1988 and again in 1989 abamectin was used under an emergency exemption of FI-FRA, Section 18, in most of the pear areas in California, Oregon, and Washington for control of spider mites, including organotinresistant populations. The widespread foliar use of abamectin and horticultural spray oil on pear has raised concerns about potential phytotoxicity. In this study we examined this problem and the plant injury risks associated with abamectin and oil treatments on several pear cultivars.

The chemicals used in these tests were abamectin (Agrimek 0.15 EC, Merck and Co., Rahway, N.J.) and three horticultural spray oils, Orchex 696, Orchex 796 (Humble Oil Co., Baytown, Texas), and Volck Supreme (Chevron, Richmond, Calif.). Orchex 796 and Volck Supreme oils are commonly used on pear during the prebloom and the foliar periods. Orchex 696 is a somewhat lighter oil used on other crops, such as cit-

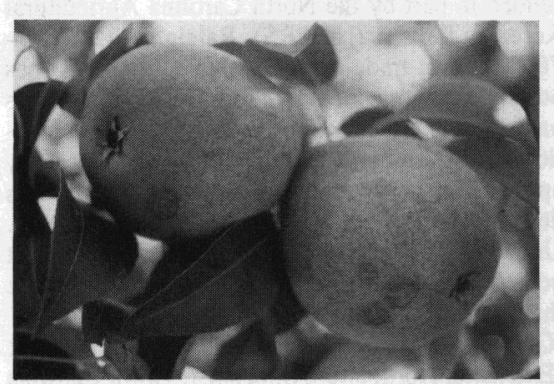

Fig. 1. Epidermal fruit injury on 'Anjou' pear resulting from application of abamectin (0.0017 $\mathrm{g}$ a.i./liter) in combination with Volck Supreme horticultural spray oil $(1 \% \mathrm{v} / \mathrm{v})$. 


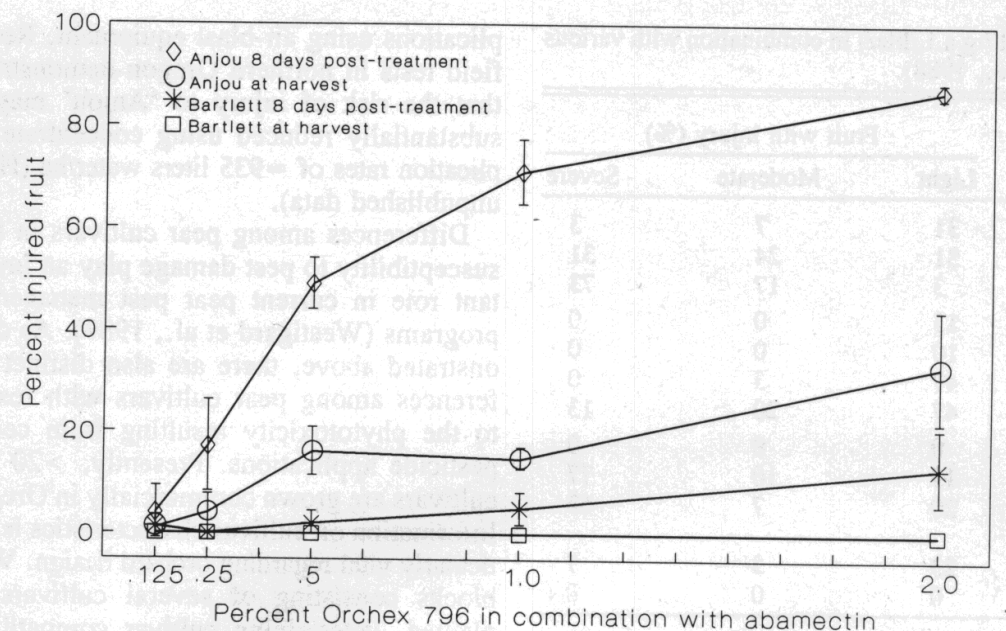

Fig. 2. Percent 'Anjou' and 'Bartlett' pear fruit with epidermal injury $>19 \mathrm{~mm}$ in diameter resulting from application of abamectin $(0.0035 \mathrm{~g}$ a.i./liter) with varying concentrations of Orchex 796 horticultural spray oil. Each point represents the mean \pm SD of four replicates.

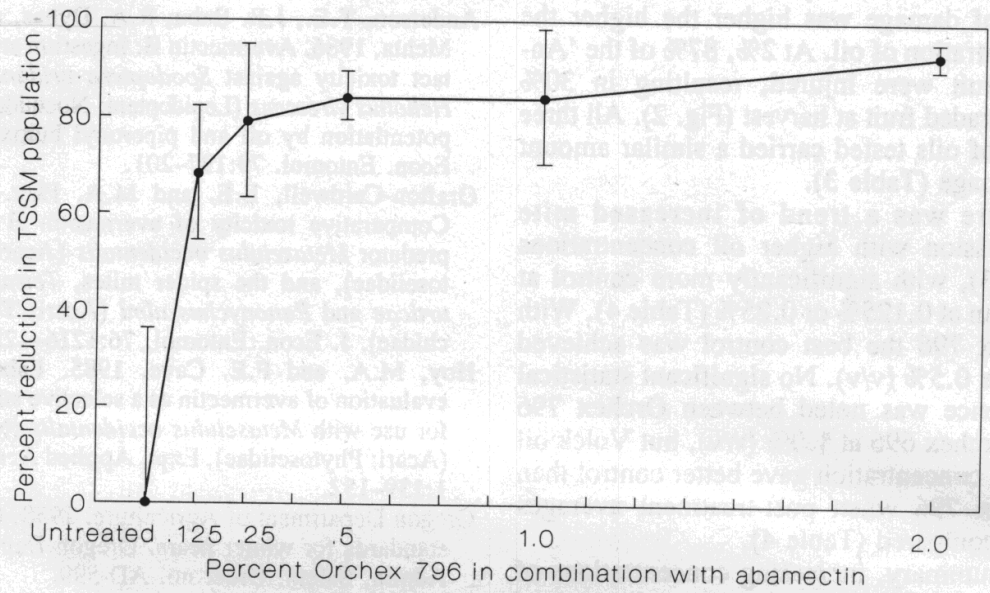

Fig. 3. Percent reduction of two spotted spider mite (TSSM) on 'Anjou' pear after application of abamectin $(0.0035 \mathrm{~g}$ a.i./liter) with varying concentrations of Orchex 796 horticultural spray oil. Each point represents the mean \pm SD of four replicates.

Table 1. Properties of horticultural spray oils used in the abamectin-oil evaluation.

\begin{tabular}{llcc}
\hline \hline & & Oil type & Volck \\
\cline { 2 - 4 } & Orchex & Orchex & Supreme \\
\hline Properties & 796 & 696 & 34.8 \\
$\begin{array}{l}\text { Gravity API at 15.6C } \\
\text { Viscosity, SUS at 37.8C }\end{array}$ & 35.3 & 37.0 & 104 \\
$\begin{array}{c}\text { Temp }\left({ }^{\circ} \mathrm{C}\right) \text { at which 50\% } \\
\text { of oil distilled }\end{array}$ & 73 & 60 & 246.7 \\
$\begin{array}{c}\text { Temp }\left({ }^{\circ} \mathrm{C}\right) \text { differential } \\
\text { between 10\% and 90\% distillation } \\
\text { of producty }\end{array}$ & 222.2 & 212.2 & \\
Unsolfonated residues $(\%)$ & 38.9 & 31.1 & 47.2 \\
\hline
\end{tabular}
zThese properties are those of the base oils without emulsifiers added for field use. Information supplied
by the manufacturers.

'Distillation method D1160 at $10 \mathrm{~mm} \mathrm{Hg}$.

rus. All three are relatively "narrow-cut," highly refined, paraffinic-base oils (Table 1). All treatments were made using conventional high-pressure handgun spray equipment with trees sprayed to runoff.

Three preliminary tests were conducted in 1988 in northern Oregon's Hood River Valley on single trees of 'Anjou'. In these trials abamectin was used at $0.0017 \mathrm{~g}$ a.i./liter in water and combined with Volck Supreme oil at $0.25 \%, 0.5 \%$, and $1.0 \%$ (v/v) on $20 \mathrm{July}$; Orchex 796 oil at $0.0625 \%, 0.125 \%, 0.25 \%$, and $0.50 \%(\mathrm{v} / \mathrm{v})$ on 4 Aug.; and with Volck Supreme and Orchex 796 at 1.0\% (v/v) along with abamectin and Volck Supreme each separately on 26 Aug. Phytotoxicity ratings were made 10 to 14 days following treatment as to degree and prominence of the injury.
Damage took the form of dark rings (Fig. 1) with the following gradations: light marking (partial or indistinct rings); moderate marking (well-defined rings); severe marking (full ring with raised borders).

Based on the Hood River results, tests were carried out in southern Oregon's Rogue River Valley in 1989 to evaluate the injury response of six pear cultivars to varying rates and types of oil used in combination with abamectin. These trials were conducted in a 0.75 -ha block of mixed pear cultivars. Standard controls for codling moth (Cydia pomonella L.) and diseases were used through the season. The block was divided into eight treatments with four replicates each in a randomized complete-block design. Each replicate contained two trees of each of the following: 'Anjou', 'Cornice', 'Bartlett', 'Sensation Red Bartlett', 'Bosc', and 'Seckel'. The treatments were Orchex 796 oil used at $0.125 \%, 0.25 \%, 0.50 \%, 1.0 \%$, and $2.0 \%$ (v/v) and Volck Supreme and Orchex 696 both used at $1 \%(\mathrm{v} / \mathrm{v})$; the control was treated with neither abamectin nor oil. Abamectin at $0.0035 \mathrm{~g}$ a.i./liter was combined with each oil treatment.

Application was made on 20 June using conventional high-pressure handgun equipment with trees sprayed to runoff. Evaluation of phytotoxicity to 25 pear fruit per variety per replicate was made 8 days after application and again at harvest. In instances where trees were weak and 25 fruit were not available for examination, replicates were eliminated. The first evaluation was based on the percentage of fruit exhibiting dark rings and the harvest evaluation on the percentage of fruit downgraded due to this injury. Fruit was downgraded if the total injured surface area exceeded $\approx 19 \mathrm{~mm}$ in diameter (Oregon Dept. of Agriculture, 1958).

In addition to phytotoxicity evaluations, the effect of the oil-abamectin combinations on density of the two spotted spider mite was measured at the southern Oregon site. Spider mites were sampled biweekly on 'Anjou' from 13 June to 21 July. Samples were composed of 20 mature leaves from each of the eight two-tree replicates. Leaves were returned to the laboratory where mites were removed using a mite-brushing machine and counted with aid of a dissecting microscope $(\times 10)$.

Spray injury. Typically, fruit damage appeared as partially or fully formed rings with a raised border. Spray rings formed where spray liquid coalesced into larger drops and adhered to the fruit surface and dried. The spray injury was located at the calyx end and on the side of the fruit where excess spray failed to run off. Injury symptoms became visible within 3 to $4 \mathrm{~h}$ after treatment. Lenticels inside the marked area were enlarged and dark (Fig. 1).

Hood River tests. Results from the preliminary studies showed increasing epidermal fruit damage with increasing concentrations of oil but with abamectin kept constant. Both Volck Supreme and Orchex 796 at $0.5 \%$ $(\mathrm{v} / \mathrm{v})$ resulted in moderate or severe injury on $55 \%$ to $33 \%$ of fruit, respectively, while $0.25 \%(\mathrm{v} / \mathrm{v})$ caused damage on $7.0 \%$ and 
Table 2. Injury response of 'Anjou' pear to abamectin $(0.0017 \mathrm{~g}$ a.i./liter $)$ in combination with various types and rates of horticultural spray oils (Hood River, Ore., 1988).

\begin{tabular}{llcrrr}
\hline \hline \multirow{2}{*}{$\begin{array}{l}\text { Treatment } \\
\text { and } \\
\text { oil type }\end{array}$} & $\begin{array}{c}\text { Oil } \\
\text { concn } \\
(\%)\end{array}$ & $\begin{array}{c}\text { Application } \\
\text { date }\end{array}$ & Light & Moderate & Severe \\
\hline Volk Supreme & 0.25 & 20 July & 31 & 7 & 3 \\
& 0.5 & 20 July & 31 & 24 & 31 \\
& 1.0 & 20 July & 3 & 17 & 73 \\
Orchex 796 & 0.0625 & 4 Aug. & 13 & 0 & 0 \\
& 0.125 & 4 Aug. & 10 & 0 & 0 \\
& 0.25 & 4 Aug. & 47 & 3 & 0 \\
Untreated & 0.5 & 4 Aug. & 47 & 20 & 13 \\
Volck Supreme & --- & 4 Aug. & 0 & 0 & 0 \\
Orchex 796 & 1.0 & 26 Aug. & 13 & 10 & 77 \\
Volck Supreme & 1.0 & 26 Aug. & 20 & 7 & 67 \\
$\quad$ (no abamectin) & 1.0 & 26 Aug. & 23 & 3 & 7 \\
Abamectin (no oil) & --- & 26 Aug. & 0 & 0 & 0 \\
\hline
\end{tabular}

Table 3. Injury response of three pear cultivars to abamectin $(0.0035 \mathrm{~g}$ a.i./liter $)$ in combination with various types of horticultural spray oils at $1 \%$ (Medford, Ore., 1989).

\begin{tabular}{|c|c|c|c|}
\hline \multirow[b]{2}{*}{ Oil } & \multicolumn{3}{|c|}{$\begin{array}{c}\text { Fruit with injury } \\
8 \text { days post-spray }(\%)^{z}\end{array}$} \\
\hline & Anjou & Comice & Bartlet \\
\hline Orchex 796 & $72.0 \mathrm{~b}$ & $49.3 \mathrm{~b}$ & $5.0 \mathrm{a}$ \\
\hline Orchex 696 & $96.0 \mathrm{~b}$ & $50.0 \mathrm{~b}$ & $4.0 \mathrm{a}$ \\
\hline Volck Supreme & $76.0 \mathrm{~b}$ & $40.0 \mathrm{~b}$ & $2.0 \mathrm{a}$ \\
\hline None & $2.0 \mathrm{a}$ & $0 \quad \mathrm{a}$ & $0 \quad a$ \\
\hline
\end{tabular}

${ }^{2}$ Mean separation in columns by Fisher's LSD test, $P=0.05$, using arcsin-transformed data. Untransformed data used in table.

$3.0 \%$ of fruit for the two oils, respectively. In the 26 Aug. test, no damage was recorded when abamectin was used alone, and only $10 \%$ of fruit were moderately to severely damaged with Volck Supreme used alone at $1 \%$ (v/v) (Table 2).

Southern Oregon test. The epidermal phytotoxicity varied not only with the concentration of oil used but also with the cultivar treated. No spray injury was observed on 'Sensation Red Bartlett' and little on 'Bosc' or 'Seckel' ( $0 \%$ to $1.3 \%$ of fruit affected), regardless of oil rate or type applied. Moderate damage to 'Bartlett' was recorded on both evaluation dates, but was not serious enough to cause downgrading at harvest (Fig.
2). The most serious damage was found on 'Anjou' and 'Cornice' (Table 3). On 'Anjou' fruit evaluated 8 days after treatment, the level of damage was higher the higher the concentration of oil. At $2 \%, 87 \%$ of the 'Anjou' fruit were injured, resulting in $30 \%$ downgraded fruit at harvest (Fig. 2). All three types of oils tested carried a similar amount of damage (Table 3).

There was a trend of increased mite suppression with higher oil concentrations (Fig. 3), with significantly more control at $2 \%$ than at $0.125 \%$ or $0.25 \%$ (Table 4 ). With Orchex 796 the best control was achieved with $\geq 0.5 \%(\mathrm{v} / \mathrm{v})$. No significant statistical difference was noted between Orchex 796 and Orchex 696 at 1.0\% (v/v), but Volck oil at that concentration gave better control than Orchex 796 when post-treatment averages were compared (Table 4).

In summary, increasing concentrations of oil in combination with a constant rate of abamectin increased the severity of fruit damage on three of six pear cultivars tested, i.e., 'Anjou', 'Cornice', and 'Bartlett'. On these senstive cultivars, the oil concentration should not exceed $0.25 \%(\mathrm{v} / \mathrm{v})$ to minimize the risk of phytotoxicity while maintaining adequate spider mite suppression. However, the dilute handgun application used in these studies appears to produce more severe damage than that resulting from commercial ap- plications using air-blast equipment. Recent field tests in northern Oregon demonstrated that the risk of injury to 'Anjou' may be substantially reduced using concentrate application rates of $\approx 935$ liters water/ha (H.R., unpublished data).

Differences among pear cultivars in their susceptibility to pest damage play an important role in current pear pest management programs (Westigard et al., 1989). As demonstrated above, there are also distinct differences among pear cultivars with respect to the phytotoxicity resulting from certain pesticide applications. Presently, >20 pear cultivars are grown commercially in Oregon. Information on cultivar characteristics is particularly vital regarding orchard design. When blocks consisting of several cultivars are planted, determining cultivar compatibility should include pest management factors such as the cultivars' sensitivity to phytotoxicity.

\section{Literature Cited}

Anderson, T.E., J.R. Babu, R.A. Dybas, and H. Mehta. 1986. Avermectin B: Ingestion and contact toxicity against Spodoptera eridania and Heliothis virescens (Lepidoptera: Noctuidae) and potentiation by oil and piperonyl butoxide. J. Econ. Entomol. 79:197-201.

Grafton-Cardwell, E.E. and M.A. Hoy. 1983. Comparative toxicity of avermectin $\mathrm{B}$ to the predator Metaseiulus occidentalis (Acari: Phytoseiidae), and the spider mites, Tetranychus urticae and Panonychus ulmi (Acari: Tetranychidae). J. Econ. Entomol. 76:1216-1220.

Hoy, M.A. and F.E. Cave. 1985. Laboratory evaluation of avermectin as a selective acaricide for use with Metaseiulus occidentalis (Nesbitt) (Acari: Phytoseiidae). Expt. Applied Acarology 1:139-152.

Oregon Department of Agriculture. 1958. Oregon standards for winter pears. Oregon Dept. Agr. Admin, Salem. Order no. AD-599.

Westigard, P.H., L.J. Gut, and W.J. Liss. 1986. Selective control program for the pear pest complex in southern Oregon. J. Econ. Entomol. 79:250-257.

Westigard, P.H., D. Sugar, P. Gonzalves, and R. Hilton. 1989, Using pear cultivars in the management of the pear pest complex. Proc. Wash. Hort. Soc. 85:206-209.

Willett, M. and P.H. Westigard. 1988. Using horticultural spray oils to control orchard pests. Pacific Northwest Coop. Ext. Bul. 328, Corvallis, Ore.

Table 4. Control of the two spotted spider mite (TSSM) with abamectin $(0.0035 \mathrm{~g}$ a.i./liter) and oil combinations on 'Anjou' pear; treated 20 June by handgun (Medford, Ore., 1989).

\begin{tabular}{|c|c|c|c|c|c|c|c|}
\hline \multirow[b]{3}{*}{ Oil } & \multirow{3}{*}{$\begin{array}{l}\text { Rate } \\
(\% \text { oil })\end{array}$} & \multicolumn{5}{|c|}{ Avg no. TSSM/leaf ${ }^{2}$} & \multirow{3}{*}{$\begin{array}{c}\text { Post-treatment } \\
\text { avg } \\
\text { (28 June-21 July) }\end{array}$} \\
\hline & & \multicolumn{2}{|c|}{ June } & \multicolumn{3}{|c|}{ July } & \\
\hline & & 13 & 28 & 7 & 14 & 21 & \\
\hline \multirow[t]{5}{*}{ Orchex 796} & 0.125 & $1.4 \mathrm{a}$ & $0.3 \mathrm{ab}$ & $1.5 \mathrm{~b}$ & $1.8 \mathrm{a}$ & $3.5 \mathrm{bc}$ & $1.8 \mathrm{~d}$ \\
\hline & 0.25 & $3.2 \mathrm{a}$ & $1.1 \mathrm{~b}$ & $0.8 \mathrm{ab}$ & $1.3 \mathrm{a}$ & $1.7 \mathrm{ab}$ & $1.2 \mathrm{~cd}$ \\
\hline & 0.50 & $3.6 \mathrm{a}$ & $0.7 \mathrm{ab}$ & $0.1 \mathrm{a}$ & $0.7 \mathrm{a}$ & $1.9 \mathrm{ab}$ & $0.9 \mathrm{bcd}$ \\
\hline & 1.0 & $3.1 \mathrm{a}$ & $0.6 \mathrm{ab}$ & $0.6 \mathrm{ab}$ & $1.2 \mathrm{a}$ & $1.3 \mathrm{ab}$ & $0.9 \mathrm{bcd}$ \\
\hline & 2.0 & $4.5 \mathrm{a}$ & $0.9 \mathrm{ab}$ & $0.1 \mathrm{a}$ & $0.1 \mathrm{a}$ & $0.6 \mathrm{a}$ & $0.4 \mathrm{ab}$ \\
\hline Orchex 696 & 1.0 & $4.1 \mathrm{a}$ & $0.7 \mathrm{ab}$ & $0.3 \mathrm{a}$ & $0.4 \mathrm{a}$ & $0.6 \mathrm{a}$ & $0.5 a b c$ \\
\hline Volck Supreme & 1.0 & $1.8 \mathrm{a}$ & $0.2 \mathrm{a}$ & $0.1 \mathrm{a}$ & $0.1 \mathrm{a}$ & $0.2 \mathrm{a}$ & $0.2 \mathrm{a}$ \\
\hline None & -.. & $0.3 \mathrm{a}$ & $5.8 \mathrm{c}$ & $9.3 \mathrm{c}$ & $2.2 \mathrm{a}$ & $5.0 \mathrm{c}$ & $5.6 \mathrm{e}$ \\
\hline
\end{tabular}

${ }^{2}$ Mean separation in columns by Fisher's LSD test, $P=0.05$, using square-root-transformed data. Untransformed data used in table. 